\title{
Quality of basic health care and social vulnerability: a spatial analysis*
}

\author{
Qualidade da atenção básica à saúde e vulnerabilidade social: uma análise espacial \\ Calidad de la atención básica y vulnerabilidad social: un análisis espacial
}

How to cite this article:

Souza KOC, Fracolli LA, Ribeiro CJN, Menezes AF, Silva GM, Santos AD. Quality of basic health care and social vulnerability: a spatial analysis. Rev Esc Enferm USP. 2021;55:e20200407. doi: https://doi.org/10.1590/1980-220X-REEUSP-2020-0407

\section{Katyucia Oliveira Crispim de Souza ${ }^{1}$

(D) Lislaine Aparecida Fracolli²
(iD) Caíque Jordan Nunes Ribeiro
(D) Andreia Freire de Menezes
(iD) Glebson Moura Silva
(D) Allan Dantas dos Santos

* Extracted from the dissertation: "Qualidade da atenção básica e sua relação com a vulnerabilidade social nos municípios do Nordeste do Brazil”, Universidade Federal de Sergipe, 2020.

${ }^{1}$ Universidade de São Paulo, Escola de Enfermagem, Programa de Pós-Graduação Interunidades em Enfermagem, São Paulo, SP, Brazil.

${ }^{2}$ Universidade de São Paulo, Escola de Enfermagem, Departamento de Enfermagem em Saúde Coletiva, São Paulo, SP, Brazil.

${ }^{3}$ Universidade Federal de Sergipe, Departamento de Enfermagem, Lagarto, SE, Brazil.

\begin{abstract}
Objective: To analyze the association between quality of basic health care and social vulnerability in municipalities of the Brazilian northeast. Method: Ecological study with spatial analysis using univariate global and local Moran's indexes. Bivariate analyses were employed to examine the relationship between the quality of basic health care and the Social Vulnerability Index in the Northeast. The dependent variable corresponded to the final scores of certifications of teams of basic health care in the Northeast that had participated in the third cycle of the Brazilian Program for the Improvement of Access and Quality of Basic Health Care. The independent variable was the Social Vulnerability Index of the municipality. Results: The bivariate analysis has pointed out the presence of areas of low vulnerability with high quality basic health care in the municipalities in the states of Piauí, Ceará, Rio Grande do Norte, Pernambuco, and Bahia. The state of Maranhão is emphasized for its low performance in basic health care in a large number of municipalities with high vulnerability. Conclusion: The study has revealed a spatial relation between the indicators of social vulnerability and quality of basic health care in the Northeast, suggesting that limitations in access to health resources and services may be related to social and health determinants.
\end{abstract}

\section{DESCRIPTORS}

Primary Health Care; Quality of Health Care; Social Vulnerability; Spatial Analysis. 


\section{INTRODUCTION}

The access and quality of health services are currently an object of discussion and political analysis, specially from the 1970s onwards, in international conferences, when integral health started to be emphasized. Since then, with the improvement of life conditions, society has been requiring increasingly more quality and equity of access to services, especially those provided by public bodies, making it fundamental that mechanisms of assessment and control of quality of care be created. Thus, governments have been searching for forms of improving efficiency, efficacy, and the capability of response by their health systems ${ }^{(1-2)}$.

In Brazil, Basic Health Care (BHC) includes a leading component of health care which enables transformations in the structure and reorganization of the health system. The expansion of the Family Health Strategy (FHS) was responsible for broadening the access and the offer of services to Brazil as a whole, mainly in the poorest and most vulnerable regions, in addition to providing the user with a major access to satisfaction of their health needs ${ }^{(3)}$.

However, even with the advancements of the National Basic Health Care Policy (Politica Nacional de Atenção Básica - PNAB) over recent years, the deep social and health inequalities in Brazil still persist and represent one of the biggest challenges to the quality and potential of the health services ${ }^{(4)}$. Social vulnerability is directly related to the social determinants of health which emerge in the daily lives of individuals in their territories and contribute to the promotion or susceptibility of their health-disease processes ${ }^{(5)}$.

The concept of vulnerability denotes the heterogeneity of concepts which are not strictly conditioned to the absence or precariousness of access to income, but also related to frailties and inequalities of access to public goods and services. Vulnerable human beings are those who are most likely to suffer with different risks and damages due to their social mobility disadvantages. Thus, individuals who are in unfavorable social conditions present higher exposure to risks in the health-disease process due to limitations in access to resources and services which help coping with illness ${ }^{(5)}$.

With the objective of strengthening BHC and thus better responding to the demands of the most vulnerable populations, the Brazilian Ministry of Health has structured the National Program for the Improvement of Access and Quality of Basic Health Care (Programa Nacional de Melhoria do Acesso e da Qualidade da Atenção Básica - PMAQ-AB) as one of the main strategies for monitoring and assessing processes and results of $\mathrm{BHC}$ to improve the structure of this component of health care. The program has the objective of understanding the determinants and different health contexts, in addition to engaging, mobilizing, and sharing responsibility among the various involved agents to produce significant change in the ways of providing and managing care so as to promote improvement of access and quality of $\mathrm{BHC}^{(6)}$.

This research has thus the objective of analyzing the association between quality of basic health care and social vulnerability in the municipalities of the Brazilian Northeast.

\section{METHOD}

\section{Design of Study}

This is an ecological study with techniques of spatial analysis and use of secondary data from PMAQ-AB and the Social Vulnerability Atlas of the Institute of Applied Economic Research (Instituto de Pesquisa Econômica Aplicada-IPEA) $)^{(7)}$.

LOCAL

The Brazilian Northeast comprises nine states: Alagoas, Bahia, Ceará, Maranhão, Paraíba, Pernambuco, Piauí, Rio Grande do Norte, and Sergipe, which amount to 1,794 municipalities. Its territorial extension of $1,554,257 \mathrm{~km}^{2}$ has circa 53,081,950 citizens, which represents around 28\% of the Brazilian population. It has a population density of 34.1 citizens $/ \mathrm{km}^{2}$ and its Human Development Index (HDI) is the smallest in Brazil: $0.608^{(8)}$.

\section{Data Collection}

The units of analysis were the municipalities of the Northeast whose BHC teams participated of the third cycle of PMAQ-AB, which corresponded to 16,215 teams distributed in 1,752 municipalities of the region. Forty-two municipalities which did not adhere to the third cycle of the program have been excluded.

The quality of $\mathrm{BHC}$ in the Northeast was represented by the arithmetic mean of the cut-point for the final scores of the certifications of the teams which have participated of the third cycle of the program in each municipality, so that each unit of analysis of the study was the municipality. The data regarding the certifications of the third cycle, which took place between 2015/2019, were obtained in the website Ministry of Health Basic Health Care Department Portal (Portal do Departamento da Atenção Básica do Ministério da Saúde - PMAQ) and varied between five performance categories, which translated score ranges from zero to ten, added to the criteria of abidance to quality standards defined by the Ministry of Health: Great (score $>=8$ ), Very good (score $>7$ to 7.99), Good (score $>6$ to 7), Average (score $>4$ to 6 ) and Bad (score 0 to 4$)^{(9)}$.

The social vulnerability of the Northeastern municipalities was represented by the municipal Social Vulnerability Index (SVI), composed of 16 indicators which represent the dimensions of Urban Infrastructure (SVI-UI), Human Capital (SVI-HC) and Income and Work (SVI-IW). The SVI varies from 0 to 1 , so that the closest to 1 , the highest the social vulnerability of a municipality; these are classified as very low (0 to 0.200$)$, low (0.201 to 0.300 ), average ( 0.301 to 0.400$)$ high (0.401 to 0.500 ), and very high $(\geq 0.501)$ social vulnerability ${ }^{(7)}$. This index was chosen due to its capability of revealing conditions of social vulnerability in the diverse scales of the Brazilian territory in the contexts of work and income, education and health, transportation conditions, housing, and sanitation. The definition of vulnerability in which this SVI is based is related to the absence or to the insufficiency of assets, 
constituting, therefore, an instrument for the identification of flaws in the offer of public goods and services in the national territory by the Brazilian state ${ }^{(7)}$.

\section{Data Treatment and Analysis}

A univariate analysis was performed through Local Indicators of Spatial Autocorrelation (LISA), based on Global Moran's Index to verify whether the spatial distribution of BHC quality occurs randomly in space. The objective of LISA is to assess whether space is a relevant variable for the studied phenomenon from the production of specific values for each territorial area which, then, identifies the cluster areas with significant patterns of spatial association with their neighbors ${ }^{(10)}$.

The distribution analysis of LISA enables the classification of the variable of interest into four clusters: high/high, i.e., observations with values above the mean, with neighborhood also above the mean; low/low clusters, those lower than the mean, with neighbors also in the same situation; high/low and low/high clusters, which represent, respectively, areas of low values surrounded by high values and areas of high values surrounded by low values. The latter two are considered spatial outliers and are defined thus as negative local spatial autocorrelations ${ }^{(10)}$.

Bivariate local Moran's index was also used to identify spatial correlations between the quality of BHC and SVI and between the quality of BHC and the dimensions of SVI so as to identify the spatial association patterns of each one and their influence on the composition of the overall SVI result. The bivariate analysis shows four types of spatial relation between the proposed variables, considering one unit of place and the neighboring units, which are characterized in this study as: high-high, high quality of basic care surrounded by high vulnerability; high-low, high quality of basic care surrounded by low vulnerability; low-high, low quality of basic care surrounded by high vulnerability; and low-low, low quality of BHC surrounded by low vulnerability ${ }^{(11)}$.

The programs TerraView version 4.2.0, QGis version 3.4.5, and $\mathrm{GeoDa}^{\mathrm{TM}} 1.14$ were used to build the maps using the cartographic basis, in the format shapefile, in the system of geographic latitude/longitude projection (Geodesic Reference System - SIRGAS 2000) of the Northeast region available on the website of the Brazilian Institute of Geography and Statistics (Instituto Brasileiro de Geografia e Estatistica - IBGE).

\section{Ethical Aspects}

Since this study uses secondary, public domain data, it did not require a project submission to the Research Ethics Committee.

\section{RESULTS}

The total of BHC teams that voluntarily adhered and participated in the third cycle of PMAQ-AB was 16.215, distributed into 1,752 municipalities of the Northeast. These values represented $37.8 \%$ of the total of teams in Brazil during 2017, according to data by the Ministry of Health, and approximately $31.5 \%$ of the total of municipalities in Brazil in that same year, according to data by IBGE.

Out of the 781 disqualified teams, $87.5 \%$ refused to answer to the external assessment and $12.5 \%$ did not have an available dental chair. Also, 23 teams were disqualified with unsatisfactory performance due to not meeting the minimum requirements of permanence in the program. The states of Maranhão ( $\mathrm{n}=12)$, Piauí $(\mathrm{n}=9)$, and Bahia $(n=8)$ stood out among those with the highest number of municipalities with no teams evaluated during the cycle.

The results of the performance certifications in the third cycle of PMAQ-AB have shown that Maranhão is the state of the Northeast with the highest percentage of teams with bad (43\%) and average (33.8\%) performance. On the other hand, Piauí presented a higher percentage of teams with very good (23\%) and great (11.2\%) performance in the region. With the exception of Maranhão, the other states presented a higher percentage of teams with good performance in relation to the other categories of classification (Table 1).

Figure 1A shows the map of distribution of certifications of the teams. The Moran's map in Figure $1 \mathrm{~B}$ enables the identification of clusters of municipalities with a high-high pattern, i.e., municipalities with a high performance whose neighbors also had a high performance, in almost all the states, with the exception of Maranhão and Sergipe. In Maranhão, there is a remarkably big cluster of municipalities of a low-low pattern, i.e., municipalities with low BHC performance whose neighbors also presented low performance. In addition to Maranhão, the states of Piauí, Bahia, and Sergipe also presented low-low patterns.

Table 2 shows the distribution of SVI of the municipalities by states of the Northeast. A predominance of municipalities with a very high SVI is observed in the states of Alagoas and Maranhão. In the states of Sergipe e Rio Grande do Norte, this relation is inverted, with approximately $10.8 \%$ of the municipalities with a very high SVI. In the state of Rio Grande do Norte, there was also a higher concentration of municipalities with low and average SVI in relation to other states of the region. The only state to present some municipality with very low SVI was Piauí.

The bivariate analysis has pointed out the presence of high-low spatial clusters, particularly in municipalities of the states of Piauí, Ceará, Rio Grande do Norte, Pernambuco, and Bahia, which corresponds to areas of low social vulnerability with high quality of basic health care. Maranhão stands out for presenting low performance in basic health care activities in many municipalities with high social vulnerability (Figure $2 \mathrm{~A}$ ).

In relation to the dimensions of SVI (Figures 2B, 2C and 2D), it is possible to observe that in all of them Maranhão presents a low BHC quality in a significant number of municipalities with high indicators of vulnerability. This same pattern is emphasized in the state of Bahia in the dimension related to SVI-IW. It was also possible to identify municipalities with a good BHC quality in areas with low indicators 
Table 1 - Distribution of certifications of the third cycle of PMAQ-AB by states in the Northeast - Aracaju, SE, Brazil, 2020.

\begin{tabular}{|c|c|c|c|c|c|c|c|c|c|c|}
\hline Performance & $\begin{array}{c}\mathrm{AL} \\
\mathrm{n}(\%)\end{array}$ & $\begin{array}{c}\text { BA } \\
\text { n (\%) }\end{array}$ & $\begin{array}{c}\text { CE } \\
n(\%)\end{array}$ & $\begin{array}{c}\text { MA } \\
\text { n (\%) }\end{array}$ & $\begin{array}{c}\text { PB } \\
\text { n (\%) }\end{array}$ & $\begin{array}{c}\text { PE } \\
\text { n (\%) }\end{array}$ & $\begin{array}{c}\text { PI } \\
\text { n (\%) }\end{array}$ & $\begin{array}{c}\text { RN } \\
\text { n (\%) }\end{array}$ & $\begin{array}{c}\text { SE } \\
\text { n (\%) }\end{array}$ & $\begin{array}{c}\text { Total } \\
\mathbf{n}\end{array}$ \\
\hline Great & $\begin{array}{c}43 \\
(4.5 \%)\end{array}$ & $\begin{array}{c}138 \\
(3.9 \%)\end{array}$ & $\begin{array}{c}298 \\
(11.2 \%)\end{array}$ & $\begin{array}{c}20 \\
(1.1 \%)\end{array}$ & $\begin{array}{c}81 \\
(4.9 \%)\end{array}$ & $\begin{array}{c}221 \\
(9.3 \%)\end{array}$ & $\begin{array}{c}146 \\
(11.2 \%)\end{array}$ & $\begin{array}{c}239 \\
(20 \%)\end{array}$ & $\begin{array}{c}12 \\
(1.9 \%)\end{array}$ & $\begin{array}{c}1198 \\
(7.4 \%)\end{array}$ \\
\hline Very good & $\begin{array}{c}193 \\
(20.1 \%)\end{array}$ & $\begin{array}{c}523 \\
(14.6 \%)\end{array}$ & $\begin{array}{c}640 \\
(24.1 \%)\end{array}$ & $\begin{array}{c}74 \\
(4 \%)\end{array}$ & $\begin{array}{c}353 \\
(21.4 \%)\end{array}$ & $\begin{array}{c}515 \\
(21.6 \%)\end{array}$ & $\begin{array}{c}299 \\
(23 \%)\end{array}$ & $\begin{array}{c}231 \\
(19.4 \%)\end{array}$ & $\begin{array}{c}84 \\
(13 \%)\end{array}$ & $\begin{array}{l}2912 \\
(18 \%)\end{array}$ \\
\hline Good & $\begin{array}{c}325 \\
(34 \%)\end{array}$ & $\begin{array}{c}1187 \\
(33.2 \%)\end{array}$ & $\begin{array}{c}755 \\
(28.5 \%)\end{array}$ & $\begin{array}{c}274 \\
(14.8 \%)\end{array}$ & $\begin{array}{c}612 \\
(37.2 \%)\end{array}$ & $\begin{array}{c}772 \\
(32.4 \%)\end{array}$ & $\begin{array}{c}346 \\
(26.6 \%)\end{array}$ & $\begin{array}{c}345 \\
(28.8 \%)\end{array}$ & $\begin{array}{c}181 \\
(28 \%)\end{array}$ & $\begin{array}{c}4797 \\
(29.6 \%)\end{array}$ \\
\hline Average & $\begin{array}{c}262 \\
(27.3 \%)\end{array}$ & $\begin{array}{c}1169 \\
(32.7 \%)\end{array}$ & $\begin{array}{c}456 \\
(17.2 \%)\end{array}$ & $\begin{array}{c}626 \\
(33.8 \%)\end{array}$ & $\begin{array}{c}420 \\
(25.7 \%)\end{array}$ & $\begin{array}{c}517 \\
(21.7 \%)\end{array}$ & $\begin{array}{c}253 \\
(19.5 \%)\end{array}$ & $\begin{array}{c}237 \\
(19.9 \%)\end{array}$ & $\begin{array}{c}150 \\
(23.3 \%)\end{array}$ & $\begin{array}{c}4090 \\
(25.2 \%)\end{array}$ \\
\hline Bad & $\begin{array}{c}116 \\
(12.1 \%)\end{array}$ & $\begin{array}{c}404 \\
(11.3 \%)\end{array}$ & $\begin{array}{c}201 \\
(7.6 \%)\end{array}$ & $\begin{array}{c}797 \\
(43 \%)\end{array}$ & $\begin{array}{c}157 \\
(9.6 \%)\end{array}$ & $\begin{array}{c}207 \\
(8.6 \%)\end{array}$ & $\begin{array}{c}228 \\
(17.5 \%)\end{array}$ & $\begin{array}{c}137 \\
(11.5 \%)\end{array}$ & $\begin{array}{c}167 \\
(25.9 \%)\end{array}$ & $\begin{array}{c}2414 \\
(14.9 \%)\end{array}$ \\
\hline Disqualified & $\begin{array}{c}20 \\
(2 \%)\end{array}$ & $\begin{array}{c}152 \\
(4.2 \%)\end{array}$ & $\begin{array}{c}296 \\
(11.1 \%)\end{array}$ & $\begin{array}{c}58 \\
(3.1 \%)\end{array}$ & $\begin{array}{c}21 \\
(1.3 \%)\end{array}$ & $\begin{array}{c}153 \\
(6.4 \%)\end{array}$ & $\begin{array}{c}28 \\
(2.2 \%)\end{array}$ & $\begin{array}{c}2 \\
(0.2 \%)\end{array}$ & $\begin{array}{c}51 \\
(7.9 \%)\end{array}$ & $\begin{array}{c}781 \\
(4.8 \%)\end{array}$ \\
\hline Unsatisfactory & $\begin{array}{c}0 \\
(0 \%)\end{array}$ & $\begin{array}{c}5 \\
(0.1 \%)\end{array}$ & $\begin{array}{c}7 \\
(0.3 \%)\end{array}$ & $\begin{array}{c}5 \\
(0.2 \%)\end{array}$ & $\begin{array}{c}4 \\
(0.2 \%)\end{array}$ & $\begin{array}{c}0 \\
(0 \%)\end{array}$ & $\begin{array}{c}0 \\
(0 \%)\end{array}$ & $\begin{array}{c}2 \\
(0.2 \%)\end{array}$ & $\begin{array}{c}0 \\
(0 \%)\end{array}$ & $\begin{array}{c}23 \\
(0.1 \%)\end{array}$ \\
\hline Total & $\begin{array}{c}959 \\
(5.9 \%)\end{array}$ & $\begin{array}{c}3578 \\
(22 \%)\end{array}$ & $\begin{array}{c}2653 \\
(16.4 \%)\end{array}$ & $\begin{array}{c}1854 \\
(11.4 \%)\end{array}$ & $\begin{array}{c}1648 \\
(10.2 \%)\end{array}$ & $\begin{array}{c}2385 \\
(14.7 \%)\end{array}$ & $\begin{array}{l}1300 \\
(8 \%)\end{array}$ & $\begin{array}{c}1193 \\
(7.4 \%)\end{array}$ & $\begin{array}{c}645 \\
(4 \%)\end{array}$ & $\begin{array}{c}16215 \\
(100 \%)\end{array}$ \\
\hline
\end{tabular}

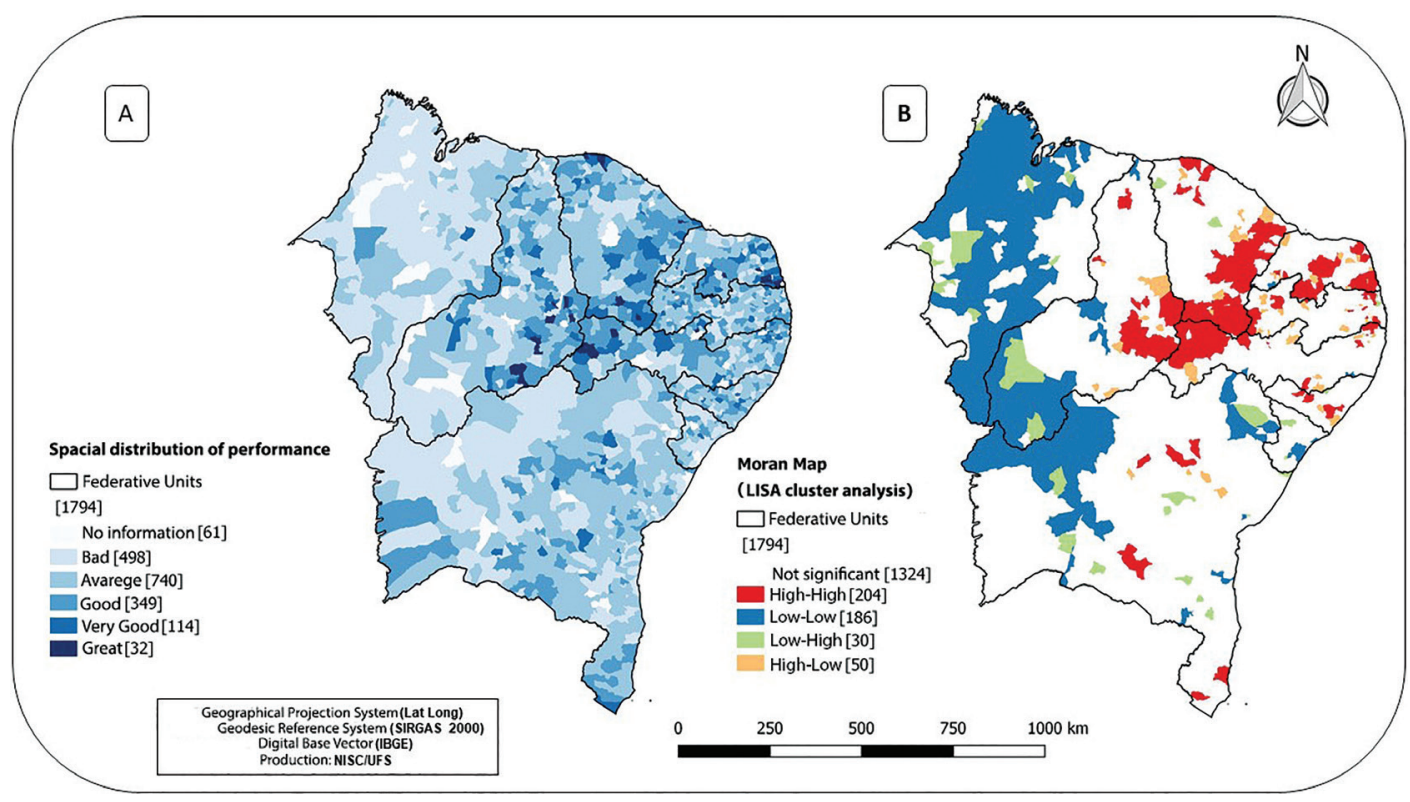

Figure 1 - Distribution and spatial autocorrelation of the performance of the BHC teams, Northeast, Brazil.

(A): Spatial distribution of the performance of the BHC teams by PMAQ- $\mathrm{AB}$; $(\mathrm{B})$ : Moran's analysis of the performance of the $\mathrm{BHC}$ teams by the $\mathrm{PMAQ}-\mathrm{AB}$, in which high-high: high BHC quality and high vulnerability; high-low: high BHC quality and low vulnerability; low-high: low quality of BHC and high vulnerability; and low-low: low BHC quality and low vulnerability.

Table 2 - Distribution of the municipalities in the states of the Northeast, per SVI - Aracaju, SE, Brazil, 2020.

\begin{tabular}{cccccccccc}
\hline SVI & AL n (\%) & BA n (\%) & CE n (\%) & MA n (\%) & PB n (\%) & PE n (\%) & PI n (\%) & RN n (\%) & SE n (\%) \\
\hline Very low & $0(0)$ & $0(0)$ & $0(0)$ & $0(0)$ & $0(0)$ & $1(0.5)$ & $0(0)$ & $0(0)$ & $0(0)$ \\
\hline Low & $0(0)$ & $5(1.2)$ & $2(1.1)$ & $1(0.5)$ & $7(3.1)$ & $0(0)$ & $3(1.3)$ & $13(7.8)$ & $1(1.3)$ \\
\hline Average & $4(3.9)$ & $79(18.9)$ & $44(23.9)$ & $9(4.1)$ & $56(25.2)$ & $23(12.4)$ & $36(16.1)$ & $53(31.7)$ & $21(28)$ \\
\hline High & $35(34.3)$ & $229(54.9)$ & $108(58.7)$ & $37(17.1)$ & $106(47.5)$ & $105(56.8)$ & $110(49.1)$ & $83(49.7)$ & $45(60)$ \\
\hline Very high & $63(61.8)$ & $104(25)$ & $30(16.3)$ & $170(78.3)$ & $54(24.2)$ & $56(30.3)$ & $75(33.5)$ & $18(10.8)$ & $8(10.7)$ \\
\hline Total & 102 & 417 & 184 & 217 & 223 & 185 & 224 & 167 & 75 \\
\hline \multicolumn{7}{c}{} \\
\hline
\end{tabular}




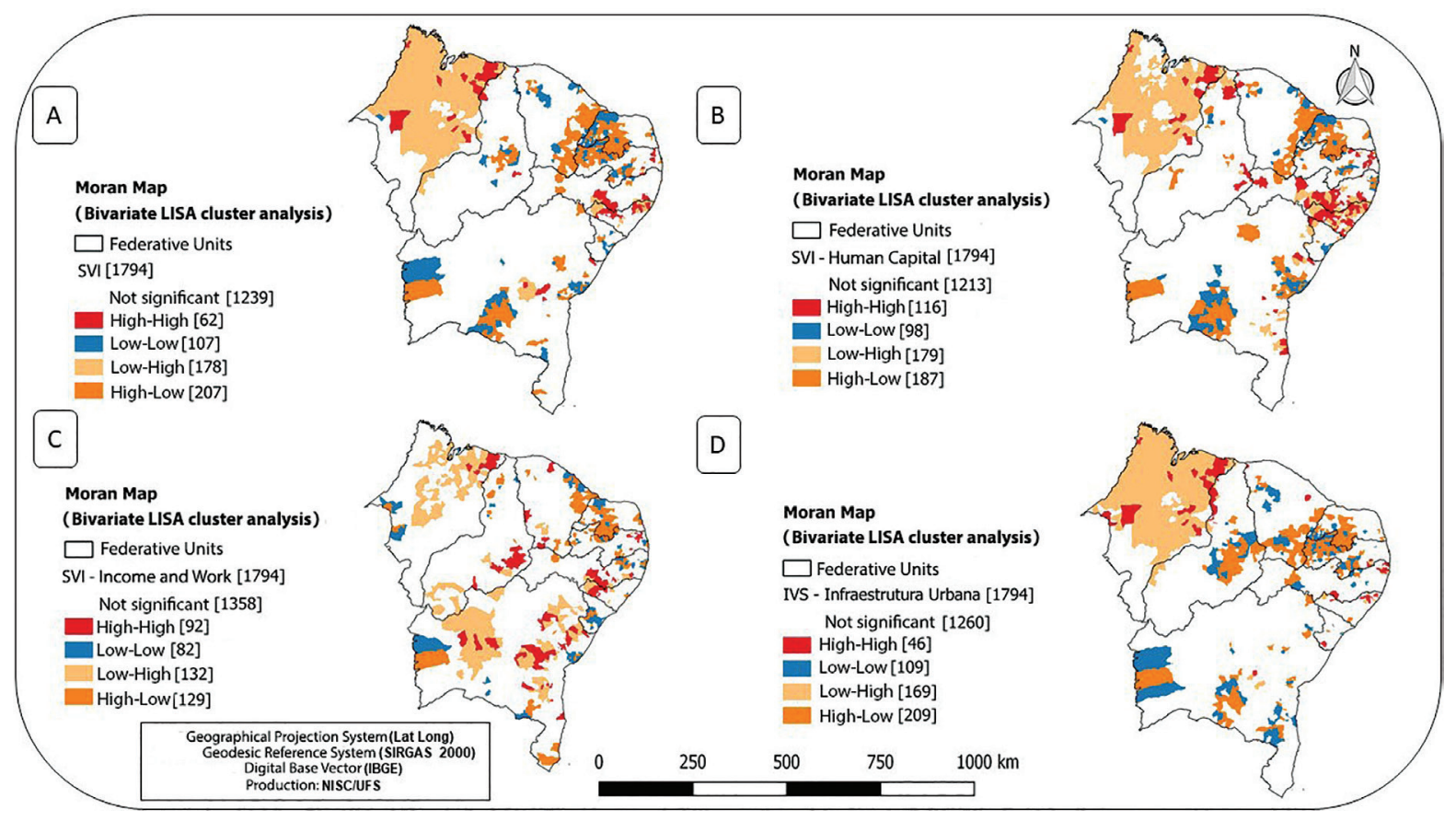

Figure 2 - Bivariate analysis of the quality of BHC and of social vulnerability, Northeast, Brazil.

(A): Moran's bivariate of quality of BHC and SVI; (B): Moran's bivariate of quality of BHC and SVI-HC; (C): Moran's bivariate of quality of BHC and SVI-IW; (D): Moran's bivariate of quality of BHC and SVI-UI.

related to the three dimensions of SVI, particularly in the states of Bahia, Ceará, Piauí, and Rio Grande do Norte.

\section{DISCUSSION}

This study aimed at gathering resources for a critical approach of space beyond the political-operative dimension of the health system with geoprocessing techniques for assessing the certifications of $\mathrm{PMAQ}-\mathrm{AB}$, given that territory is an important instrument of work processes and health practices organization. When searching for a theoretical framework to support this study in the databases National Center for Biotechnology Information (NCBI/ PubMed), Scopus, Web of Science, Biblioteca Virtual em Saúde (BVS), and Scientific Electronic Library Online (SciELO), during the search period (2019/2020), there was a scarcity of publications which assess the work and performance of basic health care teams from this perspective. Also, there was a gap regarding the use of spatial analysis for assessing health services and their different contexts.

This study has shown an inverse association between social vulnerability indicators and $\mathrm{BHC}$ quality, indicating that the smallest the social vulnerability, the higher the chances of a better quality. This result enables inferring that the criteria for the implementation of FHS should consider factors related to social determinants in addition to equity and service accessibility, with the objective of identifying flaws in the offer of public goods and services.

The historical evolution of health policies in Brazil is directly related to the political, social, and economic evolution and is organized after specific contexts and needs, in accordance with current social trends. Historical regional inequalities also influence health service conformation, with concentration of activities in coastal areas and major urban centers ${ }^{(12)}$.

Even with the emergence of the Unified Health System (Sistema Unico de Saúde - SUS) after the struggles of the Brazilian Sanitary Reform, which aimed not only at the health system, but social transformation, the territorial configuration of Brazilian regional inequalities was maintained, with a concentration of medium and high complexity equipment mainly in capitals and major cities. However, when it comes to BHC, the opposite happened: the expansion of FHS has prioritized places with less favorable socioeconomic conditions, contributing to an increase in equity of access to health and the reduction of regional disparities of various health indicators ${ }^{(12)}$.

The process of implementation of FHS was intense in the Northeast, with the expansion of the geographic coverage, due to the progressive increase in the number of municipalities adhering to the program as a consequence of their need for prioritizing public policies to overcome their social and programmatic vulnerabilities. There was a tendency of improvement in health and development indicators after the implementation of FHS, which has contributed substantially to the health system improvement ${ }^{(13)}$.

Despite its significant social improvements, the Brazilian Northeast still presents several socioeconomic problems, such as high child mortality rates (33.2 deaths for every one thousand live births) and absence of sanitation in more than half (55\%) of residencies. Currently, FHS has an estimated coverage of $81.74 \%$; Oral Health has $85.31 \%$. Also, this region has the highest number of municipalities that have 
adhered to the third cycle of PMAQ-AB, with approximately $98 \%$ of adherence ${ }^{(14)}$.

Although most Brazilian municipalities have a high BHC coverage, there are still socio-spatial and economic disparities among the regions, according to data from a study that assessed regional and social health inequality from 1998 to 2013. The North and Northeast regions presented the worst indicators throughout the time series, reinforcing that increased access does not necessarily lead to equity in quality of service, understood to be an essential factor for social justice ${ }^{(15)}$.

Corroborating this study, authors have provided low performance results in the Northeast region when assessing the quality of BHC in Brazil. States with good performances, such as Piauí and Rio Grande do Norte, were also observed, showing differences between states of this region ${ }^{(16)}$. Assessment of $\mathrm{BHC}$ must thus take into account the heterogeneity of the different geographic areas, both in terms of access and in terms of offer and demand and the possible dimensions of care.

The different classifications of BHC quality among the states may be associated to an unequal implementation of this care level in the Northeast, related to the municipalities' financial availability, management skills, and, in some cases, the availability of professionals for their teams. Since they are autonomous political and administrative units, municipalities have different capabilities for management and generating revenue. Those with more resources and organizational capabilities have a higher potential for investments in $\mathrm{BHC}^{(14)}$.

Another possible reason for the observed inequality is social vulnerability, since health is produced in spaces where people establish relations in different social, political, and economic contexts ${ }^{(17)}$. Quality goals tend to be harder to achieve in places where the population is socially vulnerable due to higher health needs and demands by their population, since poorer populations are known to be more susceptible to diseases, which implies an overload in service structure and work conditions ${ }^{(18)}$.

In the Northeast, Maranhão is the state with the highest number of municipalities with high social vulnerability. Also, it is among the Brazilian states with the smallest revenues and health investments ${ }^{(14)}$. This corroborates this study's data, according to which Maranhão stood out for presenting a performance classified as bad in most of their teams. Thus, BHC quality may have been impacted by this territory's high vulnerability.

Service quality improvement is suggested to be based not only on direct health care, but also on their social determinants, aiming at a stronger impact in care to the populations of vulnerable regions. Using vulnerability measures to plan and organize $\mathrm{BHC}$ services is useful for reducing inequality in service use through stratification of population risk, according to a study performed in Distrito Federal which assessed the vulnerability of families attended by $\mathrm{BHC}^{(19)}$.

Thus, when suggesting the articulation between territory and vulnerability, individual, collective, and contextual aspects regarding the availability or lack of resources to protect people should be included. The data and information produced by $\mathrm{PMAQ}-\mathrm{AB}$ can show problematic situations in this context due to its broad coverage. In addition, performance classifications represent the certifications of teams weighted by socioeconomic strata for fairer resource transferences which encourage equity ${ }^{(20)}$.

In this context, the relations between health problems and interventions which may solve them are subject to value judgment with the objective of helping decision making. This judgment may result from various analyses obtained by different methods and approaches. However, these results cannot be easily reduced to a small number of recommendations, since assessments aim to gather deeper information on the reasons why intervention goals are left unfulfilled ${ }^{(1)}$.

The use of indicators promotes the development of health information systems, in addition to facilitating service monitoring. The availability of valid and reliable information is crucial for the analysis of health situations and, consequently, for decision making. Poor quality of information may compromise the quality of monitoring and assessment processes ${ }^{(21-22)}$.

The set of indicators defined by PMAQ-AB refers to some of the main strategical foci of this level of attention and promotes complementation of information on service offer with the objective of reflecting the effort of the health and management teams for $\mathrm{BHC}$ quality improvement ${ }^{(23)}$. The presence of indicators related to access shows the interest in establishing mechanisms to ensure universal accessibility and welcoming of all people who seek BHC services, with no exclusion. However, health is built in spaces of life in which different social and economic contexts manifest asymmetries in health care access, despite the constitutional guarantees of equity ${ }^{(17)}$.

In this sense, $\mathrm{BHC}$ services located in vulnerable territories pose questions related to infrastructure, information, transportation, inappropriateness of certain health equipment facilities, difficulties in workers' access to people and in people's access to workers ${ }^{(24)}$. This is thus a broader process of construction of conditions of life with objectives related, but not limited, to the health sector ${ }^{(17)}$.

In Brazil, access to health is strongly influenced by socioeconomic conditions and residence area. People with better socioeconomic conditions who live in more developed regions have a better access to health services. However, there is a trend for individuals with lower socioeconomic conditions to make more use of services after having access to them. In this sense, for a better, equitable health access and promotion, planning activities to identify and analyze mechanisms and consequences of vulnerability that influence the effectivity of health services is necessary ${ }^{(25-26)}$.

This study has also observed some places scattered across Maranhão, Piauí, and Bahia that presented a high quality of BHC with low vulnerability. A possible explanation for this finding would be the direct influence of basic care on the development of its area of coverage, 
since it contributes to improvements in the life conditions of individuals and collectives ${ }^{(17)}$.

Curative-preventive practice, as in the traditional biomedical model, may be circumvented and broadened making the health teams responsible for the population in their work area, trying also to encompass aspects relating to subjective life and family life, work, environment, social relations, aesthetics, and culture to promote a better quality of life. This includes one of the main principles of change of the health care model, which consists of working with the social determinants of health ${ }^{(17)}$.

Regarding the association of $\mathrm{BHC}$ quality with the dimensions of SVI, the conditions of access to services of basic sanitation and urban mobility, factors related to income and current and future perspectives in health and education of individuals were observed to possibly influence the performance of $\mathrm{BHC}$ teams ${ }^{(27)}$. The three dimensions represent sets of structures or resources, also known as "assets", whose possession or deprivation determines the well-being of populations in contemporary societies. Thus, the definition of vulnerability as per SVI refers to the access, absence, or insufficiency of such assets, constituting an instrument for the identification of flaws in the offer of public goods and services in the territory ${ }^{(7)}$.

In addition to being timely, health services must be safe, effective, and resolutive to identify needs, solving health problems of users and offering both initial consultation and other procedures in $\mathrm{BHC}$ until the qualified referral to specialized care when necessary. For teams to achieve their resolutive potential, managers and professionals must analyze and intervene, in accordance with their reality, on aspects related to the structure of their services ${ }^{(27)}$.

The increase in risk exposure in the health-disease process, as well as the limitation of access to resources and services, may be related to social determinants of health and socioeconomic, gender, ethnic, racial, and geographical differences. Thus, the purpose of suggesting the articulation between quality of basic care and vulnerability is overcoming the individual dimension, encompassing collective and contextual aspects, as well as the availability or lack of resources for protecting people ${ }^{(28)}$.
In this configuration, among the professionals who integrate the FHS teams, nurses frequently take on planning, managing, maintenance, and assessment of the health service's actions and indicators, which commonly justifies the coordination of the process and the search for the quality standards suggested by PMAQ. This is shown by PMAQ data in which, within the team, the professionals assign the nurse with the role of cognitive authority in communicating information about the processes of work organization ${ }^{(29)}$.

This position, which is being taken by nurses as coordinators/managers of BHC teams, suggests an extension of limits to professional activity, overcoming strictly care-related tasks. In addition, "management is also part of care and must be carried out with responsibility and commitment to health needs to provide care practices, whose foci of attention lie on the collective and the family"(30).

Thus, the relevance of this study's findings is the possibility of contributing not only to the development of public policies aimed at high quality of care and the equity of health services in Brazil, but also to orient, in particular, nurses in charge of team management and coordination for the elaboration of efficient BHC modifications. However, such changes cannot be artificially produced by ordinances, but should rather involve all the processes, internal means, and complexities of the user's environment.

\section{CONCLUSION}

By assessing BHC quality from the perspective of its association with social determinants, the teams with the best performances were identified to be in areas with low social vulnerability. Deeper knowledge about contextual factors associated to quality are believed to be the starting point for reorganization of work and health management.

Even with the influence of other variables, such as underfunding, change of population epidemiological profile, poor management, and increase in users' demands, the perspective of territory observation proposes more complex and longitudinal care practice, which may enable the integration of care networks with other areas related to health in addition to intersectoral actions capable of modifying the social determinants of health.

\section{RESUMO}

Objetivo: Analisar a associação entre a qualidade da atenção básica e a vulnerabilidade social nos municípios do Nordeste brasileiro. Método: Estudo ecológico com análise espacial, utilizando os índices de Moran global e local univariados. As análises bivariadas foram empregadas para examinar a relação entre a qualidade da atenção básica e o Índice de Vulnerabilidade Social no Nordeste. A variável dependente correspondeu às notas finais de certificações das equipes de atenção básica do Nordeste que participaram do terceiro ciclo do Programa Nacional de Melhoria do Acesso e da Qualidade da Atenção Básica. A variável independente foi o Indice de Vulnerabilidade Social municipal. Resultados: A análise bivariada apontou presença de áreas de baixa vulnerabilidade com alta qualidade da atenção básica em municípios dos estados do Piauí, Ceará, Rio Grande do Norte, Pernambuco e Bahia. O Maranhão destacou-se por apresentar baixo desempenho da atenção básica em um grande número de municípios com alta vulnerabilidade. Conclusão: $\mathrm{O}$ estudo revelou a relação espacial entre indicadores de vulnerabilidade social e qualidade da atenção básica no Nordeste, sugerindo que limitações no acesso a recursos e serviços de saúde podem estar relacionados a determinantes sociais de saúde.

\section{DESCRITORES}

Atenção Primária à Saúde; Qualidade da Assistência à Saúde; Vulnerabilidade Social; Análise Espacial.

\section{RESUMEN}

Objetivo: Analizar la asociación entre la calidad de la atención básica y la vulnerabilidad social en municipios del Nordeste de Brasil. Método: Estudio ecológico con análisis espacial, utilizando índices de Moran globales y locales univariados. Se emplearon análisis bivariados para examinar la relación entre la calidad de la atención básica y el Índice de Vulnerabilidad Social en el Nordeste. La 
variable dependiente fue las puntuaciones finales de las certificaciones de los equipos de asistencia básica del Nordeste que participaron en el tercer ciclo del Programa Nacional de Mejoramiento del Acceso y la Calidad de la Atención Básica. La variable independiente fue el Índice de Vulnerabilidad Social municipal. Resultados: El análisis bivariado mostró la presencia de áreas de baja vulnerabilidad con alta calidad de atención básica en los municipios de los estados de Piauí, Ceará, Rio Grande do Norte, Pernambuco y Bahia. El estado de Maranhão se destacó por presentar un bajo desempeño de la atención básica en un gran número de municipios con alta vulnerabilidad. Conclusión: El estudio reveló la relación espacial entre los indicadores de vulnerabilidad social y la calidad de la atención básica en el Nordeste, sugiriendo que las limitaciones en el acceso a los recursos y servicios de salud pueden estar relacionadas con los determinantes sociales de la salud.

\section{DESCRIPTORES}

Atención Primaria de Salud; Calidad de la Atención de Salud; Vulnerabilidad Social; Análisis Espacial.

\section{REFERENCES}

1. Souza EA, Cossentini LA. A melhora da assistência ao cliente por meio da gestão da qualidade em saúde. Braz J Surg Clin Res. 2017;18(2):95-7.

2. Pereira GS, Pereira SS. A importância da qualidade do serviço na gestão hospitalar. Rev Eletr Atualiza Saúde. 2015;1(1):109-17.

3. Morosini MVGC, Fonseca AF, Lima LD. Política Nacional de Atenção Básica 2017: retrocessos e riscos para o Sistema Único de Saúde. Saúde Debate. 2018;42(116):11-24. https://doi.org/10.1590/0103-1104201811601

4. Viacava F, Oliveira RAD, Carvalho C, Laguardia J, Bellido JG. SUS: oferta, acesso e utilização de serviços de saúde nos últimos 30 anos. Ciênc Saúde Coletiva. 2018;23(6):1751-62. https://doi.org/10.1590/1413-81232018236.06022018

5. Carmo ME, Guizardi, FL. O conceito de vulnerabilidade e seus sentidos para as políticas públicas de saúde e assistência social. Cad Saúde Pública. 2018;34(3):e00101417. https://doi.org/10.1590/0102-311x00101417

6. Flôres GMS, Weigelt LD, Rezende MS, Telles R, Krug SBF. Gestão pública no SUS: considerações acerca do PMAQ-AB. Saúde Debate. 2018;42(116):243-247. https://doi.org/10.1590/0103-1104201811619

7. Instituto de Pesquisa Econômica Aplicada. Atlas da vulnerabilidade social nos municípios brasileiros [Internet]. Brasília: IPEA; 2015 [cited 2020 abr. 25]. Available from: http://ivs.ipea.gov.br/images/publicacoes/lvs/publicacao_atlas_ivs.pdf

8. Banco do Nordeste. Nordeste em mapas [Internet]. Brasília; 2020 [cited 2020 ago. 11]. Available from: https://www.bnb.gov.br/ documents/88765/89729/nordeste-mapas.pdf/9e8eaaa7-1 dbf-43b7-8ed6-58046400df34?version = 1.0

9. Brasil. Ministério da Saúde. Programa Nacional de Melhoria do Acesso e da Qualidade (PMAQ). Retratos da Atenção Primária [Internet] Brasília; 2020 [cited 2020 ago. 11]. Available from: https://retratos.hmg.navi.ifrn.edu.br/

10. Anselin L. Local Indicators of Spatial Association - LISA. Geogr Anal. 1995;27:93-115. https://doi.org/10.1111/j.1538-4632.1995.tb00338.x

11. Anselin L. Exploring a spatial data with GeoDaTM: a workbook. Illinois: Center for Spatially Integrated Social Science, University of Illinois; 2005.

12. Albuquerque MV, Viana ALD'A, Lima LD, Ferreira MP, Fusaro ER, lozzi FL. Desigualdades regionais na saúde: mudanças observadas no Brasil de 2000 a 2016. Ciênc Saúde Coletiva. 2017;22(4):1055-64. https://10.1590/1413-81232017224.26862016

13. Carvalho FC, Vasconcelos TB, Arruda GMMS, Macena RHM. Modificações nos indicadores sociais da região nordeste após a implementação da atenção primária. Trab Educ Saúde. 2019;17(2):e0018925. http://dx.doi.org/10.1590/1981-7746-sol00189

14. Brasil. Ministério da Saúde, Departamento de Atenção Básica. Relatório Cobertura da Atenção Básica [Internet]. Brasília; 2020 [cited 2020 abr. 25]. Available from: https://egestorab.saude.gov.br/paginas/acessoPublico/relatorios/relHistoricoCobertura.xhtml

15. Viacava F, Porto SM, Carvalho CC, Bellido JG. Desigualdades regionais e sociais em saúde segundo inquéritos domiciliares (Brasil, 19982013). Ciênc Saúde Coletiva. 2019;24(7):2745-60. https://10.1590/1413-81232018247.15812017

16. Abreu DMX, Pinheiro PC, Queiroz BL, Lopes EAS, Machado TGM, Lima AMLD, et al. Análise espacial da qualidade da Atenção Básica em Saúde no Brasil. Saúde Debate. 2018;42(n.esp):67-80. https://doi.org/10.1590/0103-11042018S105

17. Frutoso MFP, Mendes R, Rosa KRM, Castro e Silva CR. Gestão local de saúde em território de vulnerabilidade: motivações e racionalidades. Saúde Debate. 2015;39(105):337-49. https://doi.org/10.1590/0103-110420151050002003

18. Cookson R, Asaria M, Ali S, Shaw R, Doran T, Goldblatt P. Health equity monitoring for healthcare quality assurance. Soc Sci Med. 2018;198(1):148-56. https://doi.org/10.1016/j.socscimed.2018.01.004

19. Silva TMR, Alvarenga MRM, Oliveira MAC. Avaliação da vulnerabilidade de famílias assistidas na Atenção Básica. Rev Latino Am Enfermagem. 2012;20(5): https://doi.org/10.1590/S0104-11692012000500016

20. Matta-Machado ATG, Santos AF, Abreu DMX, Jorge AO, Reis CMR, Lima AMLD, et al. Asistencia sanitaria, certificación de calidad y apoyo institucional: la atención primaria en Brasil. Rev Salud Publica Méx. 2016;58(3):358-65. http://dx.doi.org/10.21149/spm.v58i3.7895

21. Sousa AN. Monitoramento e avaliação na atenção básica no Brasil: a experiência recente e desafios para a sua consolidação. Saúde Debate. 2018;42(n.esp):289-301. https://doi.org/10.1590/0103-11042018S119

22. Albuquerque C, Martins M. Indicadores de desempenho no Sistema Único de Saúde: uma avaliação dos avanços e lacunas. Saúde Debate. 2017;41(n.esp):118-37. https://doi.org/10.1590/0103-11042017S10

23. Carvalho MF, Vasconcelos MIO, Silva ARV, Meyer APGFV. Utilização de monitoramento e análise de indicadores na Atenção Primária à Saúde. SANARE. 2017;16(01):67-73.

24. Mota ST, Vicentin MCG. Visibilidade, estigmatização e territorialização: percepções acerca da vulnerabilidade na Atenção Básica à Saúde. Distúrbio Comun. 2017;29(1):158-71. http://dx.doi.org/10.23925/2176-2724.2017v29i1p158-171 
25. Dilélio AS, Tomasi E, Thumé E, Silveira DS, Siqueira FCV, Piccini RX, et al. Padrões de utilização de atendimento médico ambulatorial no Brasil. Cad Saúde Pública. 2014;30(12):2594-606. http://dx.doi.org/10.1590/0102-311x00118713.

26. Shrestha R, Flacke J, Martinez J, Maarseveen MV. Environmental health related socio-spatial inequalities: identifying "hotspots" of environmental burdens and social vulnerability. Int J Environ Res Public Health. 2016;13(7). http://dx.doi.org/10.3390/ijerph13070691

27. Facchini LA, Tomasi E, Dilélio AS. Qualidade da Atenção Primária à Saúde no Brasil: avanços, desafios e perspectivas. Saúde Debate. 2018;42(n.esp.1):208-23. http://dx.doi.org/10.1590/0103-11042018S114

28. Barros MBA, Lima MG, Medina LPB, Szwarcwald CL, Malta DC. Social inequalities in health behaviors among Brazilian adults: National Health Survey, 2013. Int J Equity Health. 2016;15(1):1-10. http://dx.doi.org/10.1186/s12939-016-0439-0

29. Oliveira IC, Weiller TH, Soder RM, Santos JLG, Peiter CC. Programa nacional de melhoria do acesso e da qualidade da atenção básica: visão de enfermeiros. Cogitare Enferm. 2020;25:e62846. http://dx.doi.org/10.5380/ce.v25i0.

30. Galavote HS, Zandonade E, Garcia ACP, Freitas PSS, Seidl H, Contarato PC, et al. O trabalho do enfermeiro na atenção primária à saúde. Esc Anna Nery. 2016;20(1):90-8. https://doi.org/10.5935/1414-8145.20160013 